\title{
Structural Diversity and Role of Phytochemicals against P38- $\alpha$ Mitogen-activated Protein Kinase and Epidermal Growth Factor Receptor Kinase Domain: A Privileged Computational Approach
}

\author{
Amar Shankar1, S.M. Gopinath ${ }^{2}$, Shiva Prasad Kollur ${ }^{3}$, P. Sushma ${ }^{4}$, \\ Anisha S. Jain ${ }^{5}$, Sharanagouda S. Patil ${ }^{6}$, Chandrashekar Srinivasa ${ }^{2}$, \\ Shivalingaiah ${ }^{7}$ and Chandan Shivamallu ${ }^{4 *}$ (D)
}

\author{
${ }^{1}$ Department of Food Technology, School of Engineering and Technology, JAIN (Deemed-to-be University), \\ Bangalore - 562 112, Karnataka, India. \\ ${ }^{2}$ Department of Studies in Biotechnology, Davangere University, Shivagangotri, Davangere - 577002, \\ Karnataka, India. \\ ${ }^{3}$ Department of Sciences, Amrita School of Arts and Sciences, Mysuru, Amrita Vishwa Vidyapeetham - 570 \\ 026, Karnataka, India. \\ ${ }^{4}$ Department of Biotechnology and Bioinformatics, School of Life Sciences, JSS Academy of Higher \\ Education and Research, Mysuru - 570015, Karnataka, India. \\ ${ }^{5}$ Department of Microbiology, School of Life Sciences, JSS Academy of Higher Education and Research, \\ Mysuru - 570015, Karnataka, India. \\ ICAR-National Institute of Veterinary Epidemiology and Disease Informatics (NIVEDI), Yelahanka, \\ Bengaluru -560064, Karnataka, India. \\ ${ }^{7}$ Department of Botany, Maharani's Science College for Women, Mysuru- 570005, India.
}

\begin{abstract}
Computational databases and tools in recent times have been proved to provide an essential aid for anticancer studies in the field of oncology. Molecular docking studies facilitate the structural diversity of plant-derived phytomolecules having anticancer properties against receptor proteins involved in cancer signaling pathways. The current study involves the investigation of phytocompounds-agasthisflavone, anacardic acid, zoapatanolide A, a purified product of the plant extract Amarogopinois546 were subjected to docking studies on $p 38-\alpha$ MAPK and EGFR Kinase domain. The effectiveness of this study was evaluated by comparing the docking interactions of a standard drug, doxorubicin against the receptor molecules. The docking study is analyzed by compound estimated with lowest binding energy is considered to have the highest affinity towards the active site of the receptor proteins. The isolated plant compound Amarogopinois546 displayed the least binding score with a large number of hydrogen bonds and hydrophobic interactions towards the P38 $\alpha$ MAP kinase receptor in comparison with the EGFR kinase domain. This preliminary result can strongly be supported for carrying out experimental evaluation in near future.
\end{abstract}

Keywords: Phytomolecules, Docking, Binding Energy, Hydrophobic, MAPK, EGFR

*Correspondence: chandans@jssuni.edu.in; +91 $9538500423 \quad$ (Received: May 28, 2021; accepted: August 20, 2021) 


\section{INTRODUCTION}

Ayurveda is a sacred precept of rule or commandments which guides us about all aspects of life and it is considered to be the oldest healing science in India. Anacardium occidentale commonly known as Cashew belongs to the family Anacardiaceae considered as a multi-purpose tree since the leaves and the bark of the tree are of therapeutic importance and the fruit is an edible resource of high value. Anacardium occidentale native of Brazil is an all-purpose tree that is widely distributed in India, Brazil, Africa, Mexico, Malaysia, and Turkey. Vitamin B2 and $B 3$, vitamin E, vitamin C, pantothenic acid and magnesium are all abundant in cashews. Zoapatanolide A, Agasthisflavone, and anacardic acid are the biological components identified in substantial quantities in the powdered leaf extract and Cashew nutshell liquid, These phytochemicals were checked for their in-silico anticancer activity. Molecular Docking is a computational in-silico approach that helps in predicting the preferred orientation of a molecule (ligand) when it is made to interact at the binding pocket of a macromolecule (enzyme/protein) ${ }^{1}$. This knowledge of orientation prediction may in turn help in predicting the binding affinity or the strength of association between two molecules ${ }^{2}$. The in-silico molecular docking has become an efficient technique in the field of drug discovery for structure-based medication disclosure ${ }^{3}$. The most popular and commonly used software for molecular docking purposes is AutoDock (v.4.0). It is freely available open-source software for virtual screening of small molecules to receptors and computational docking ${ }^{4}$. To obtain preliminary data, docking studies were conducted using the screened phytocompounds as ligands and the target molecules p38-MAPK (p38-mitogen-activated protein kinase) and EGFR (Epidermal growth factor receptor) Kinase domain (3W2S). The target protein, p38 mitogen-activated protein kinase belongs to serine/threonine protein kinases. The human p38 MAP kinase is classified into four isoforms: $p 38 \alpha, p 38 \beta, p 38 \gamma$ and $p 38 \delta$, with $p 38 \alpha$ being the most well-studied of the four. Phosphorylation of nuclear and cytoplasmic targets is carried out by the p38 MAP kinase ${ }^{5}$. p38 MAP kinase is a signaling pathway that regulates a complex network of proteins involved in cellular activity, cell senescence, cell cycle arrest, cell differentiation, tumor suppression, apoptosis and cytokine synthesis ${ }^{6,7}$.

\section{MATERIALS and METHODS \\ Protein preparation}

The structure of proteins, 4FA2 (mitogenactivated protein kinase) and 3W2S (epidermal growth factor receptor) were obtained from Protein Data Bank (PDB) 8 and proteins devoid of the ligand is represented in Fig. 1. The protein structures were validated through the Ramachandran plot depicted in Fig. 2. Only structures which had at least $~ 96 \%$ of residues in favored regions and $\sim 2 \%$ of residues in allowed regions were fit for molecular interaction studies. Ramachandran plot prediction for the structure of

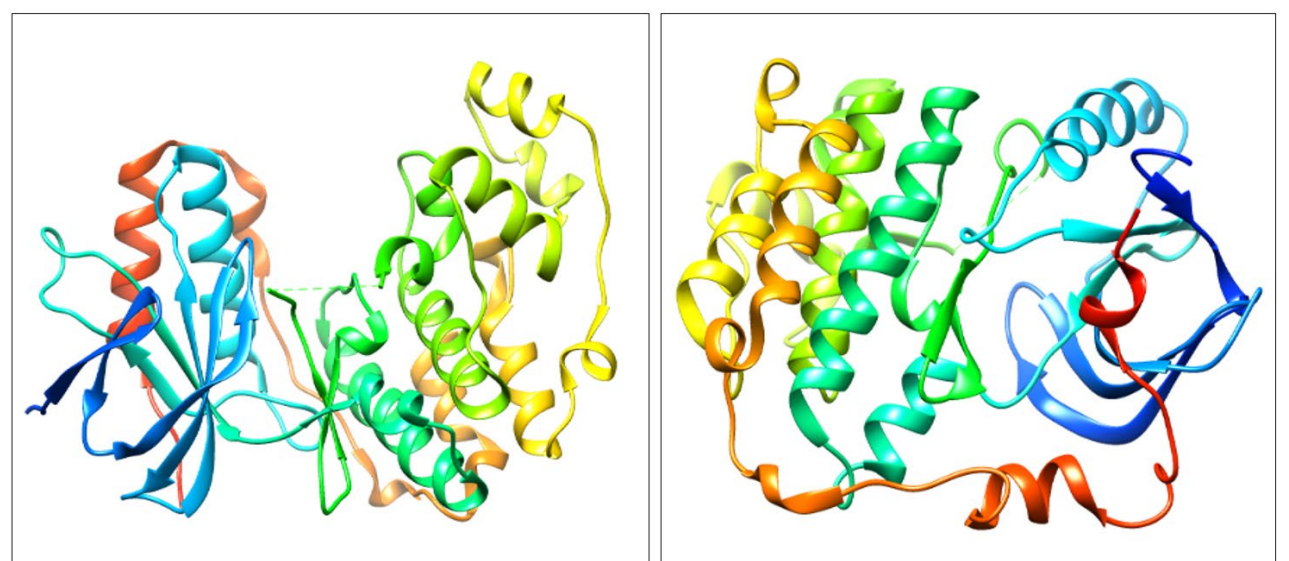

Fig. 1. 3D structure of P38 $\alpha$ MAP kinase (4FA2) and EGFR Kinase domain (3W2S). 
p38 $\alpha$ MAP kinase protein showed 97.9\% residues in favored regions and for EGFR Kinase domain protein $97.7 \%$ residues in favored regions ${ }^{9}$.

\section{Ligand Preparation}

The structure of agasthisflavone, anacardic acid, zoapatanolide $A$ and standard drug doxorubicin were obtained from Pubchem. The obtained SDF format of the above-mentioned ligands was converted to .pdb format using Open Babel (2.4.0) by adding hydrogens and generating 3D coordinates ${ }^{10}$. The purified product of the plant extract Amarogopinois546 was drawn using Chemsketch and saved in .mdl format which was further converted into .pdb format ${ }^{11}$. The geometry of all these PDB structures was cleaned and refined using Argus Lab (4.0.1) ${ }^{12}$. The validated structure which obeyed structure-activity relationships (SAR) was selected and the structures of agasthisflavone,

Table 1. The details of amino acid residues of both $4 \mathrm{FA} 2$ and $3 \mathrm{~W} 2 \mathrm{~S}$

No. Protein Binding site residues PDB ID

1 4FA2 30V, 38V, 53K, 71E, 75L, 84I, 104L, 106T, 109M, 110G, 111A, 167L, 168D, 169F

$23 \mathrm{~W} 2 \mathrm{~S}$ 718L, 726V, 743A, 745K, 795F, 796G, 797C, 800D, 801Y, 841R, 842N, 844L, $854 \mathrm{~T}, 997 \mathrm{~F}$ anacardic acid, zoapatanolide A, doxorubicin and the Amarogopinois546 are represented in Fig. 3.

The binding residues for the proteins P38 $\alpha$ MAP kinase (4FA 2) and EGFR Kinase domain (3W2S) were predicted using the GalaxySite tool of GalaxyWEB server ${ }^{13}$. Each protein showed the involvement of more than 6 residues in the formation of the active site (Table 1).

\section{Molecular Docking}

The predicted protein structures docked using Autodock suite (v.4.0) ${ }^{14}$. Autodock is a set of automated docking tools, which predicts the interactions between a small molecule and its receptor proteins, which proposes several binding modes of a docked complex ${ }^{15,16}$. It employs the Lamarckian genetic algorithm, with Gasteiger performing the charge computations. All of the chosen ligands were docked using a Genetic algorithm, in which the ligands were subjected to conformational modifications to find the lowest energy conformation, considered as the most stable structure ${ }^{16}$. The binding modes with the lowest energies were screened and grouped. The chosen compounds were docked against the target proteins to identify and evaluate the binding affinity of the docked complexes ${ }^{18,19}$. The molecular docking complexes were further visualized using the UCSF Chimera visualization tool to manually pick the best feasible docking pose ${ }^{20}$.

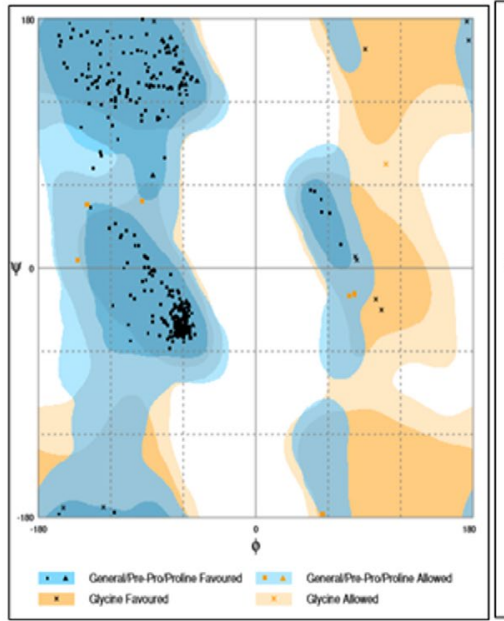

Number of residues in favoured region (-98.0\% expected) : $: 328$ (97.9\%) Number of residues in allowed region $(-2.0 \%$ expectied) $\quad: 7$ (2.1\%) Number of residves in outlier region

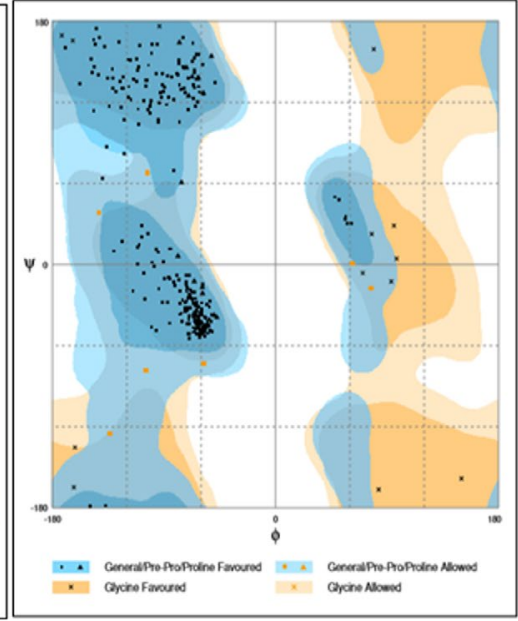

Number of residues in favoured region (-98.0\% expected) : 296 (97.7\%) Number of residues in allowed region $(-2.0 \%$ expected $) \quad: 7(23 \%)$ Number of residues in outlier region $\quad: 0(0.0 \%)$

Fig. 2. Ramachandran plot prediction for structure 4FA2 and 3W2S. 


\section{RESULTS AND DISCUSSION}

The molecular interaction studies performed through molecular docking using Autodock (4.2.6) of agathisflavone, anacardic acid, zoapatanolide $A$, doxorubicin and the
Amarogopinois546 against the P38 $\alpha$ MAP kinase (4FA2) and EGFR Kinase domain (3W2S) exhibited binding affinity and molecular interactions with proteins (Table 3 and 4 ). Whereas, binding affinity towards P38 $\alpha$ MAP kinase (4FA2) showed
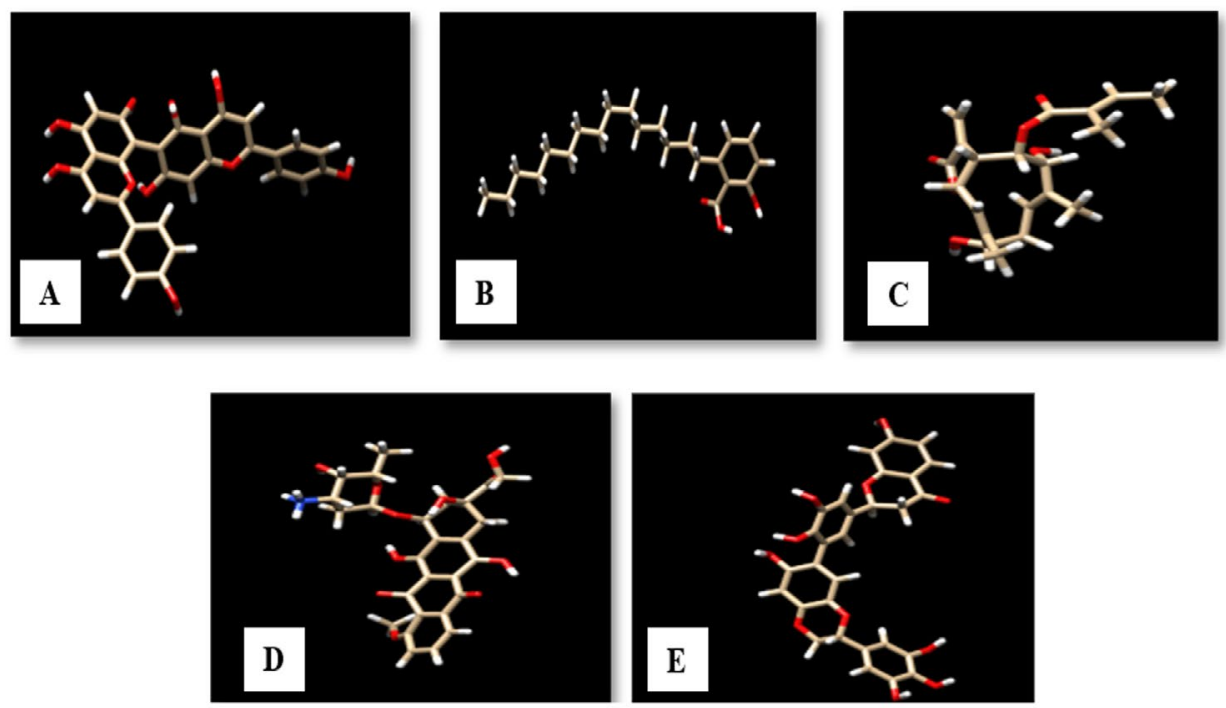

Fig. 3. 3D structure of A: Agasthisflavone, B: Anacardic acid, C: Zoapatanolide A, D: Doxorubicin and E: Amarogopinois546.

Table 2. Residues of the target molecule p38 $\alpha$ MAP kinase interacting with the three ligands: Zoapatanolide A, Agasthisflavone and Anacardic acid, a standard drug Doxorubicin and Amarogopinois546.

\begin{tabular}{|c|c|c|c|c|}
\hline \multirow{2}{*}{$\begin{array}{l}\text { Name of the } \\
\text { Biomarker }\end{array}$} & \multirow[b]{2}{*}{ Ligands } & \multicolumn{2}{|c|}{$\mathrm{H}$-bond interaction } & \multirow{2}{*}{$\begin{array}{l}\text { Amino acid residues of targe } \\
\text { (Hydrophobic } \\
\text { interactions) }\end{array}$} \\
\hline & & $\begin{array}{l}\text { No. of } \\
\text { bonds }\end{array}$ & $\begin{array}{l}\text { Amino acid } \\
\text { Residues }\end{array}$ & \\
\hline \multirow{17}{*}{$\begin{array}{l}\text { p38 } \alpha \text { MAP } \\
\text { kinase (4FA2) }\end{array}$} & Agasthisflavone & 4 & Ala 157 & Ala 157, Leu 156, Asn 155, Pro 153, \\
\hline & & & Leu 171 & Asp 112 , Ser 154 , Gly 170 , Leu 171 \\
\hline & & & Gly 31 & Leu 104 , Lys 53, Val 52, Val 38 \\
\hline & & & Leu 156 & Gly 31 , Val 30, Ser 32 \\
\hline & Anacardic acid & 1 & UNL & $\begin{array}{l}\text { Leu } 74 \text {, Leu } 75 \text {, Ile } 84 \text {, Ile 166, Leu 167, } \\
\text { Asp 168, Phe 169, Glu 71, Thr 106, Ala157 }\end{array}$ \\
\hline & Zoapatanolide A & 2 & UNL & Ser 154, Lys 152, Asn 155, Leu 171 \\
\hline & & & Ser 154 & \\
\hline & Doxorubicin & 4 & UNL & Phe 169, Gly 170 , Lys 53, \\
\hline & (standard drug) & & UNL & Leu 171 , Gly 33 , Ser 32 , Ser 154 , \\
\hline & & & Lys 53 & Gly 31, Val 163, Lys 162 \\
\hline & & & Gly 170 & \\
\hline & Amarogopinois546 & 6 & UNL & Thr 106 , His 107 , Leu 108 , Ile 84 , Lys 165 , \\
\hline & & & UNL & Gly 110, Leu 167, Val 158, Ala 157, \\
\hline & & & Met 109 & Leu 156, Ala 111, Asn 155, Ser 154, \\
\hline & & & Gly 110 & Pro 153, Asp 112, Leu 113, \\
\hline & & & Leu 156 & Gly 170 , Leu 171 , Gly 33, Ser 32 \\
\hline & & & Lys 165 & \\
\hline
\end{tabular}


Table 3. Residues of the target molecule EGFR Kinase domain interacting with Zoapatanolide A, Agasthisflavone, Anacardic acid, a standard drug Doxorubicin and Amarogopinois546

\begin{tabular}{|c|c|c|c|c|}
\hline \multirow{2}{*}{$\begin{array}{l}\text { Name of the } \\
\text { Biomarker }\end{array}$} & \multirow[t]{2}{*}{ Ligands } & \multicolumn{2}{|c|}{$\mathrm{H}$-bond interaction } & \multirow{2}{*}{$\begin{array}{l}\text { Amino acid residues of target proteins } \\
\text { (Hydrophobic interactions) }\end{array}$} \\
\hline & & $\begin{array}{l}\text { No. of } \\
\text { bonds }\end{array}$ & $\begin{array}{l}\text { Amino acid } \\
\text { Residues }\end{array}$ & \\
\hline \multirow{11}{*}{$\begin{array}{l}\text { EGFR Kinase } \\
\text { domain } \\
(3 w 2 s)\end{array}$} & Agasthisflavone & 4 & $\begin{array}{l}\text { UNL } \\
\text { UNL } \\
\text { Ala } 722 \\
\text { Met } 793\end{array}$ & $\begin{array}{l}\text { Ala 157, Leu 156, Asn 155, Pro 153, Asp 112, Ser 154, } \\
\text { Gly 170, Leu171, Leu 104, Lys 53, Val 52, Val 38, } \\
\text { Gly 31, Val 30, Ser } 32\end{array}$ \\
\hline & Anacardic acid & 3 & $\begin{array}{l}\text { Ala } 722 \\
\text { Phe } 723\end{array}$ & $\begin{array}{l}\text { Leu 74, Leu 75, Ile 84, Ile 166, Leu 167, Asp 168, } \\
\text { Phe 169, Glu 71, Thr 106, Ala157 }\end{array}$ \\
\hline & & & Gly 724 & \\
\hline & Zoapatanolide A & 2 & Ala 722 & Ser 154, Lys 152, Asn 155, Leu 171 \\
\hline & Doxorubicin & 4 & UNL & \\
\hline & (standard drug) & & $\begin{array}{l}\text { UNL } \\
\text { Ala } 722\end{array}$ & $\begin{array}{l}\text { Phe } 169 \text {, Gly } 170 \text {, Lys } 53 \text {, Leu } 171 \text {, Gly } 33 \text {, Ser } 32, \\
\text { Ser } 154 \text {, Gly } 31 \text {, Val } 163 \text {, Lys } 162\end{array}$ \\
\hline & & & $\begin{array}{l}\text { Phe } 723 \\
\text { UNL }\end{array}$ & \\
\hline & & & UNL & Leu 718, Gly 719, Ser 720, Val 726, Phe 997, Met 793, \\
\hline & Amarogopinois546 & 5 & LYS 745 & Gly 796, Asp 800, Arg 803, Leu 1001, Leu 844, Lys \\
\hline & & & MET 793 & 745, Asp 855 \\
\hline & & & ARG 803 & \\
\hline
\end{tabular}

\section{Ligands docked with 4FA2}

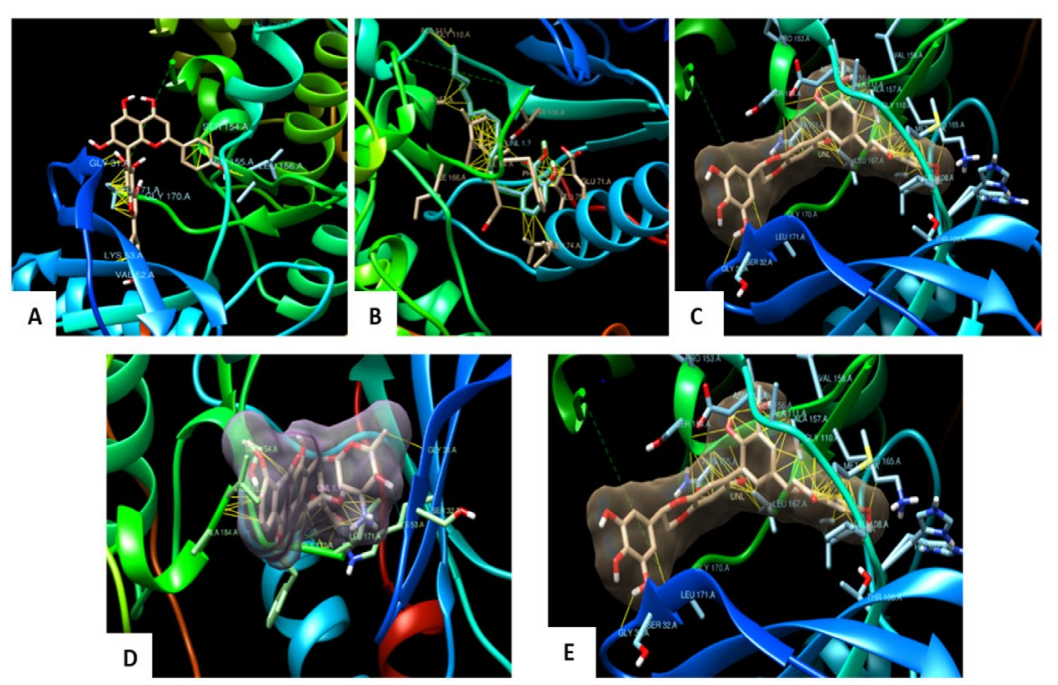

Fig. 4. Docked pose of the ligand shown with p38 $\alpha$ MAP kinase protein and Hydrophobic interactions displayed within the solid surface of the docked complex between the binding residues of the p38 $\alpha$ MAP kinase receptor and the small molecule A: Agasthisflavone, B: Anacardic acid, C: Zoapatanolide A, D: Doxorubicin and E: Amarogopinois546. 


\section{Ligands docked with EW2S}
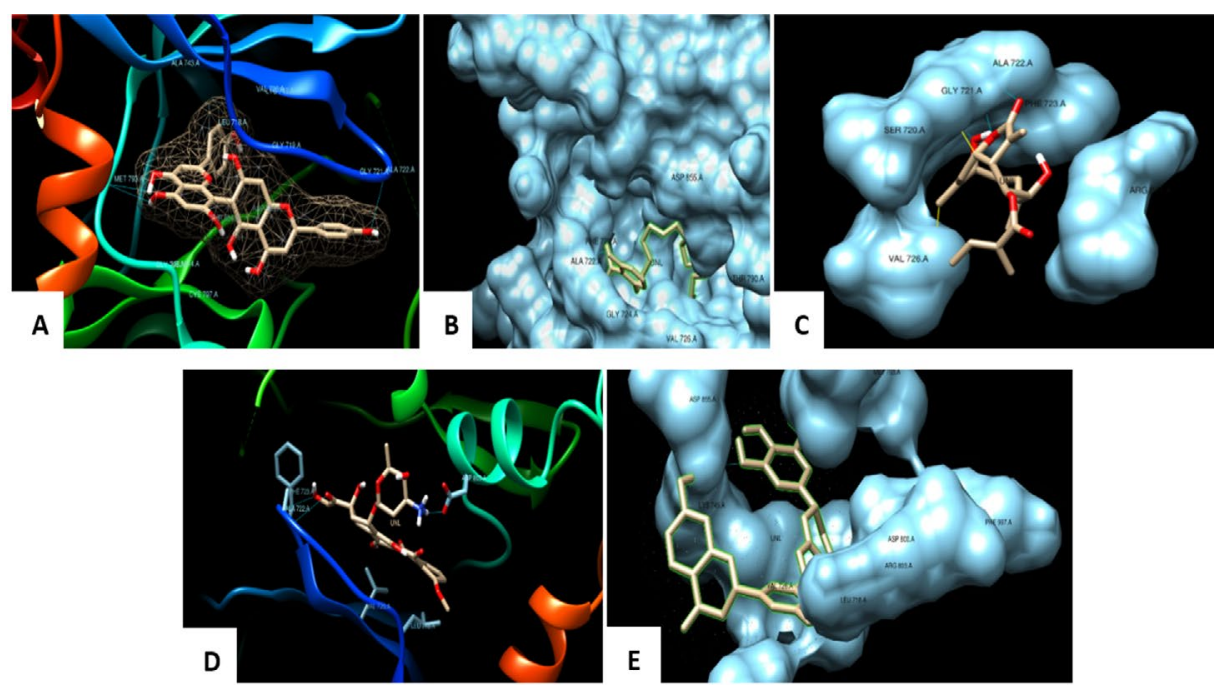

Fig. 5. Docked pose of the ligand shown with EGFR Kinase protein and the binding pocket of the EGFR protein fits the ligand by interactions and bonds A: Agasthisflavone, B: Anacardic acid, C: Zoapatanolide A, D: Doxorubicin and E: Amarogopinois546

significant binding towards all the ligand molecules. All the interactions were visualized using UCSF Chimera ${ }^{21}$ and the depicted pictures were shown in Figs. 4 and 5.

\section{Ligand interactions with 4FA2 and 3W2S}

All the ligands selected have shown a very high binding affinity and low binding energy towards 4FA2 protein when compared to $3 \mathrm{~W} 2 \mathrm{~S}$ protein. However, the screened phytomolecule Amarogopinois546 has shown a greater number of hydrogen bonds and hydrophobic interactions with both 4FA2 and 3W2S when compared to other ligands and standard drug doxorubicin. Thus, by making it a novel compound.

From the above interaction studies results obtained, the main isolated phytochemical Amarogopinois546 exhibited high binding affinity and lowest binding energy with the formation of a greater number of bonded (hydrogen bonds) and non-bonded interactions (hydrophobic interactions) towards the P $38 \alpha$ MAP kinase receptor (4FA2) which infers that the isolated phytochemical Amarogopinois546 has interacted very well with both the proteins when compared to the standard drug Doxorubicin (Inhibitor). Researchers have discovered that p38 MAP kinase plays a significant impact in cancer ${ }^{20}$.

\section{CONCLUSION}

The in silico studies were designed by selecting screened phytocompounds as ligands and target proteins as p38- $\alpha$ MAPK (p38- $\alpha$ mitogen-activated protein kinase) and EGFR Kinase domain (3W2S). The selected ligands were compared with the isolated compound Amarogopinois546 and standard drug doxorubicin. The objective concluded that Amarogopinois546 showed a high binding affinity towards the P38 $\alpha$ MAP kinase receptor (4FA2) when compared to the EGFR Kinase domain (3W2S). Thereby concluding all the predefined objectives of this investigation with the following future aspects.

\section{ACKNOWLEDGMENTS}

Amar Shankar acknowledges the support and infrastructure provided by School of Engineering and Technology, JAIN (Deemed-tobe University). KSP gratefully thank the Director, Amrita Vishwa Vidyapeetham, Mysuru campus, Mysuru for infrastructural facilities. CS and SKP acknowledge the support and infrastructure provided by the JSS Academy of Higher Education and Research (JSSAHER), Mysuru, India. 


\section{CONFLICT OF INTEREST}

The authors declare that there is no conflict of interest.

\section{AUTHORS' CONTRIBUTION}

AS, GSM, SPK, SP, ASJ, SSP, CS, and CS conceptualized and gathered the data with regard to this work. AS, CS and SP gave the necessary inputs towards the designing of the manuscript.

\section{FUNDING}

None.

\section{DATA AVAILABILITY}

All datasets generated or analyzed during this study are included in the manuscript.

\section{ETHICS STATEMENT}

Not applicable.

\section{REFERENCES}

1. Azam SS, Abbasi SW. Molecular docking studies for the identification of novel melatoninergic inhibitors for acetylserotonin-O-methyltransferase using different docking routines. Theor Biol Med Model. 2013;10:63. doi: 10.1186/1742-4682-10-63

2. Umesh HR, Ramesh KV, Devaraju KS. Molecular docking studies of phytochemicals against trehalose6-phosphate phosphatases of pathogenic microbes. Beni Suef Univ J Basic Appl Sci. 2020;9:5. doi: 10.1186/ s43088-019-0028-6

3. Acharya R, Chacko S, Bose P, Lapenna A, Pattanayak SP. Structure Based Multitargeted Molecular Docking Analysis of Selected Furanocoumarins against Breast Cancer. Sci Rep. 2019;9:15743. doi: 10.1038/s41598019-52162-0

4. Forli S, Huey R, Pique ME, Sanner MF, Goodsell DS, Olson AJ. Computational protein-ligand docking and virtual drug screening with the AutoDock suite. Nat Protoc. 2016;11(5):905-919. doi: 10.1038/ nprot.2016.051

5. Sebolt-Leopold JS. Development of anticancer drugs targeting the MAP kinase pathway. Oncogene. 2000;19(56):6594-6599. doi: 10.1038/sj.onc.1204083

6. Olson MO. Sensing cellular stress: another new function for the nucleo 2004;224:10. doi: 10.1126/stke.2242004pe10

7. Pearson BJ, Alvarado AS. Regeneration, stem cells, and the evolution of tumor suppression. Cold Spring Harb Symp Quant Biol. 2008;73:565-572. doi: 10.1101/ sqb.2008.73.045

8. Berman HM, Westbrook J, Feng Z, et al. The Protein Data Bank. Nucleic Acids Res. 2000;28(1):235-242. doi: 10.1093/nar/28.1.235

9. Pettersen EF, Goddard TD, Huang CC, et al. UCSF Chimera--a visualization system for exploratory research and analysis. J Computat Chem. 2004;25(13):1605-1612. doi: 10.1002/jcc.20084

10. Wang W, Xia M, Chen J, et al. Data set for phylogenetic tree and RAMPAGE Ramachandran plot analysis of SODs in Gossypium raimondii and G. arboretum. Data in Brief. 2016;9:345-348. doi: 10.1016/j. dib.2016.05.025

11. Ko J, Park H, Heo L, Seok C. GalaxyWEB server for protein structure prediction and refinement. Nucleic Acids Res. 2012;40(W1):W294-W297. doi: 10.1093/ nar/gks493

12. O'Boyle NM, Banck M, James CA, Morley C, Vandermeersch T, Hutchison GR. Open Babel: An open chemical toolbox. J Cheminform. 2011;3:33. doi: 10.1186/1758-2946-3-33

13. Naz A, Bano K, Bano F, Ghafoor NA, Akhtar N. Conformational analysis (geometry optimization) of nucleosidic antitumor antibiotic showdomycin by Arguslab 4 software. Pak J Pharm Sci. 2009;22(1):7882.

14. Dallakyan S, Olson AJ. Small-molecule library screening by docking with PyRx. Methods Mol Biol. 2015;1263:243-50. doi: 10.1007/978-1-4939-22697_19

15. Prasad A, Shruthi G, Sushma P, et al. Helicobacter pylori infection: a bioinformatic approach. International Journal of Pharmaceutical Sciences and Research. 2020;11(11):1000-1015.

16. Chaudhari R, Li Z. PyMine: a PyMOL plugin to integrate and visualize data for drug discovery. BMC Res Notes. 2015;8:517. doi: 10.1186/s13104-015-1483-3

17. Jain AS, Sushma P, Dharmashekar C, et al. In silico evaluation of flavonoids as effective antiviral agents on the spike glycoprotein of SARS-CoV-2. Saudi J Biol Sci. 2021;28(1):1040-1051. doi: 10.1016/j. sjbs.2020.11.049

18. Dharmashekar C, Pradeep S, Jain AS, et al. Virtual screening of potential phyto-candidates as therapeutic leads against SARS-CoV-2 infection. Environmental Challenges. 2021;4:100136. doi: 10.1016/j. envc.2021.100136

19. Prasad SK, Pradeep S, Shimavallu C, et al. Evaluation of Annona muricata Acetogenins as Potential Anti-SARS-CoV-2 Agents Through Computational Approaches. Front Chem. 2021;8:624716. doi: 10.3389/fchem.2020.624716

20. Bursulaya BD, Totrov M, Abagyan R, Brooks CL III. Comparative study of severalalgorithms for flexible ligand docking. J Comput Aided Mol Des. 2003;17(11):755763. doi: 10.1023/B:JCAM.0000017496.76572.6f

21. Avinash KO, Sushma P, Chandan S, et al. In Silico Screened Flavanoids of Glycyrrhiza glabra Inhibit Cpla2 And Spla2 In Lps Stimulated Macrophages. Bull Env Pharmacol Life Sciences. 2021;10(4):14-24. 